\title{
SNAI2 Gene
}

National Cancer Institute

\section{Source}

National Cancer Institute. SNAI2 Gene. NCI Thesaurus. Code C50877.

This gene plays a role in development. It is also involved in repression of gene transcription and inhibition of apoptosis. 